CESIS Electronic Working Paper Series

Paper No. 365

\title{
Determinants of self-employment among commuters and non-commuters
}

Mikaela Backman

Charlie Karlsson

May, 2014 


\title{
Determinants of self-employment among commuters and non-commuters
}

\author{
Authors: \\ Mikaela Backman* \\ Charlie Karlsson \\ Centre for Entrepreneurship and Spatial Economics (CEnSE) Center for Science and \\ Innovation Studies (CESIS), \\ Jönköping International Business School, Jönköping, Sweden
}

\begin{abstract}
In this paper, we analyse the determinants of the decision to become self-employed among commuters and non-commuters. In the entrepreneurship literature it is claimed that the richness and quality of an individual's business, professional and social networks play an important role for the decision to become self-employed. People that commute between localities in the same region or between localities in different regions will most probably be able to develop richer personal networks than non-commuters, since they can develop network links both in the locality where they live and in the locality where they work. In this paper, we test this hypothesis using micro-data for around three million individuals in Sweden. As far as we know, this is the first time this hypothesis is tested. In our empirical analysis, we make a distinction between three groups of individuals: non-commuters, intraregions commuter and inter-region commuters. For each of this groups we test how the probability of becoming self-employed is influenced by a number of characteristics of individuals, characteristics of home and work localities and regions. Our results indicate a significant difference between non-commuters and commuters in terms of the role of networks for becoming self-employed. On the one hand, we find for non-commuters that living and working in a locality with rich business networks reduce the probability of becoming self-employed. For commuters, on the other hand we find that working in a locality with rich business networks increase the probability to become self-employed. In this latter case, living in a municipality with rich business networks has a non-significant effect on the probability of becoming self-employed. Our results indicate that it is the business networks where people work, rather than where they live that exerts a positive influence on the probability of becoming self-employed.
\end{abstract}

Keywords: entrepreneurship, individual attributes, regional attributes, networks, micro-level data

JEL Codes: C21, J24, L26, R12

*Corresponding author 


\section{Introduction}

In this paper we analyse how the labour market behaviour of individuals influence the probability that they will turn from employment to self-employment. In an earlier paper (Backman and Karlsson 2013), we among other things showed that the probability of commuters becoming self-employed is positively influenced by the accessibility to entrepreneurs in their work locality, while the same accessibility in their home locality was insignificant. We interpreted this as an indication of the importance of the business, professional and social networks that individuals build up in their work localities that are critical for becoming self-employed while the networks they build up in their home municipality play an insignificant role.

In this paper, we broaden and deepen our earlier analysis in several ways. Firstly, we check for, if being a commuter earlier, influence the probability of non-commuters to become selfemployed, i.e. if old business, social and professional networks may play a role for the decision among current non-commuters to become self-employed later in life. Secondly, we analyse if the duration of the commuting career among current commuters influence the decision to become self-employed. The idea here is that it probably take several years to build up the necessary networks in the work locality to have got all the different contacts that might be critical for becoming self-employed. Fourthly, we make separate estimations for four aggregated occupational categories and for different educational levels.

Our empirical results show, for non-commuters, that living and working in a locality (municipality) with rich "business networks" in terms of accessibility to self-employed reduces the probability of becoming self-employed but if, on the other hand the locality is located in a labour market region (commuting region) with rich "business networks" increases the probability of becoming self-employed. Interestingly, if a non-commuter earlier has been a commuter that decreases the probability of becoming self-employed.

For commuters that commute within a labour market region our results show that working in a locality with rich "business networks" increases the probability of becoming self-employed for all categories analysed except those with an occupation within management and administration. For these commuters it is only for one of seven categories - cognitive occupations - that rich "business networks" in the region has a positive effect on the probability of becoming self-employed and for one category - social occupations - the effect is even significantly negative. Years of commuting have a significant positive effect on the probability of becoming self-employed for six of the seven categories.

Turning now to long-distance commuters, i.e., people that commute between different labour market regions the effect of "business networks" on the probability of becoming selfemployed varies substantially. For people in cognitive occupations we get significant positive effects from rich "business networks" in both the home and the work locality as well as from the home region. People in management and administrative occupations rich "business networks " in the home locality has a positive effect on the probability of becoming selfemployed, while rich "business networks" in the work locality has a negative effect. For social occupations we find a positive effect from rich "business networks" in the home locality and a negative effect from rich "business networks" in the work region. For people 
with standardised occupations we get no significant effects. People with a low education get a positive effect from rich "business networks in the home locality but the opposite from rich "business networks" in the work locality. For those with a medium education we found a significant positive effect from rich "business networks" in the home locality. For people with higher education all the network effects were insignificant. For all groups of long-distance commuters we found that the probability of becoming self-employed increased significantly with the number of commuting years.

This paper is organized as follows: In Section 2, we discuss the foundations and formation of "entrepreneurship" networks and their role individuals' decisions to become entrepreneurs, i.e. to become self-employed. Section 3 present our empirical design with chosen variables and empirical results. The last section, 4 , concludes the paper.

\section{2. "Entrepreneurship" networks: their foundations, their formation and their role for new firm formation}

In this section, we develop the theoretical foundations for our main hypotheses that the density of the "entrepreneurship" networks in the locality where people work has a significant positive influence on their probability of becoming self-employed, i.e. to become entrepreneurs. We do so by first discussing the foundations for and the formation of general economic networks in Sub-section 2.1. In Sub-section 2.2, we concentrate the focus on the foundations for and formation of general social networks, since the entrepreneurship literature today contains numerous contributions illustrating the importance of private, business and professional networks for the start-up, launching and running of a new business. In the last sub-section (Sub-section 2.3), we identify a condensed form of social networks, that we name "entrepreneurship" networks and highlight their critical role in several dimensions for peoples' willingness to become entrepreneurs. We focus on the mechanisms behind the formation of these networks and in which spatial milieus these networks are formed. However, the critical point here is if there are systematic differences in terms of which "entrepreneurship" networks that are most important for entrepreneurship, namely those in the locality where a person live or those in the locality where a person works.

\subsection{Economic models of networks}

Economic models for the emergence of networks - 'connections' models' (Jackson and Wolinsky 1996) - cope with circumstances where actors have the possibility to set up bilateral links with other actors in order to get access to something that they value. When all the actual links are added together they form a network. In the connection model, each actor initially possess some information. When a link is established between actor $i$ and actor $j$ that allows actor $i$ to access not only the information possessed by actor $j$ but also to other information, which actor $j$ has access to via his other links (and vice versa for actor $i$ ). Furthermore, the larger the distance in the network between actor $i$ and actor $j$, the lesser the degree to which actor $i$ will have access to the information possessed by actor $j$.

In our case the nodes, i.e., the actors, are represented by individuals. This implies that the networks we are interested in can be called social networks. The existing links in a network 
should be interpreted as capital objects, since they represent sunk costs. This implies that networks bring rigidity and structure into the interaction patterns at all spatial scales, since they tend to reduce interaction costs between the nodes in the network. Network links achieve capital properties since their establishment is the result of a link-specific investment that has to be carried by both nodes, i.e. individuals, but often to varying degree. When, for example, two individuals decide (explicitly or implicitly) to establish a joint link and thus a network, it is possible to think of this as the outcome of an evolutionary, gradual search and trial process. Thus, we may regard the outcome as a Nash equilibrium of a non-cooperative game, where each part would lose by leaving the network.

It is possible to introduce a spatial dimension into the connections' model by making the costs of establishing a link dependent upon actors spatial location. In a model presented by Johnson and Gilles (2003), geographic space is represented by a unit-length line along which the actors are located at fixed intervals. It is assumed that the cost of creating a link between two actors increases linearly with the distance on the line between the two actors. In a similar model developed by Carayol and Roux (2007), actors are located on a circle at equidistant intervals, and therefore do not initially occupy asymmetrical positions.

Within a network equilibrium both these models for reasonable large parameter intervals generate 'small-world' networks, i.e. networks characterized by very high rates of proximity links and relatively few long-distance links. 'Small world' networks satisfy two conditions: i) a small diameter of the network as well as a low average distance between the actors inside the network, and ii) a high clustering coefficient relative networks where links are created through a random process. The two models predict that spatial proximity is a central determining factor for collaborative choices, i.e. for the establishment of links. The rationale behind this is quite simple. It is more rational, ceteris paribus, for an actor to establish a link to another actor who is close by, rather than to an actor that is far away when the initial information endowment of each actor is equal and when the cost of creating a link to a nearby actor is lower. However, when actors in a network only have formed links to nearby actors, it might be worthwhile for an actor to substitute a nearby link with a more distant link due to the extra information he can gain indirectly from the distant actor's other links despite the higher costs for establishing a distant link.

It is possible in this kind of models that in network equilibrium the number of distant links is too low in a network. This implies an efficiency problem: when one actor establishes a long distance link, this generates a positive externality for the nearby actors to which he has a link and it may now be the case that no other actor is motivated to establish a second distant link even if that would gain the network as such, since for the individual actor the cost of establishing a distant link might be higher than the gain for this individual actor.

This kind of simple models can be extended by assuming heterogeneity among actors. Jackson and Rogers (2005) constructed a model where actors are brought together on 'islands', where the cost of establishing links on 'islands' are lower than the costs of establishing links between 'islands'. With this model the authors are able to identify all stable networks and they find that all these networks are 'small world' networks as well as efficient networks. A 
second possible extension is the keep the assumption of complete heterogeneity and analyse the creation of networks as a dynamic process. Carayol and Roux (2009) models the formation of networks through a stochastic process disrupted by the establishment of links which makes it possible to analyse the structural attributes of the network equilibrium for different values of the distance decay function. They show that for a rather wide parameter value interval the network equilibrium is made up of 'small world' networks that are characterized by a high proportion of local links and a low average distance. In a somewhat earlier study Carayol, et al. (2008) use genetic algorithms and Monte Carlo simulations to get a better understanding of the characteristics of efficient networks and the instruments to determine the degree of inefficiency of created networks. Their results show that longstanding equilibrium networks tend to have a too low density and that the long-distance links tend to be too few but also that long-distance links should be more structured around actors with a central location in the network. Central actors are those with most links within the network but it can also be those actors that functions as network 'gatekeepers', i.e. those actors that create links between groups of actors who are scattered and thereby improve the diffusion of information and knowledge.

The connections' models briefly described above have several common assumptions of which some may be questionable. One questionable assumption is that no learning is taking place, i.e., there is no increase in the different actors' knowledge due to the interaction in the network. It is questionable because it has been stressed in the literature that repeated interaction between actors reduces the cognitive distance between them (Nooteboom 2004). When the knowledge base of actors become more similar due to repeated interaction, this might reduce to the willingness to continue to interact, since the options for further learning are reduced.

The possibility that actors might want to reduce interaction or even stop interacting with some other actors when the options for future learning are reduced is dealt with in a model by Cowan, et al. (2006), which integrates the 'past-dynamic' into the network creation process. Here, the establishment and the destruction of links between firms is an ongoing process, which is influenced by the specific changing characteristics of firms following the interaction with other firms. At each stage of the process, every individual firm has a certain stock of knowledge and every firm deliberately chooses the firms with which is wants to interact. The motivation is that each firm through its interactions get an opportunity to combine its knowledge with the knowledge possessed by other firms and through that combination create new knowledge, which can be used to innovate. It such attempt has a certain probability to succeed and if it succeeds then the new knowledge created is used as an input in an innovation process. The newly created knowledge is also added to the firm's knowledge stock. Interestingly, it is not in the interest of the firms to continue a successful interaction, since repeated interaction has a lower probability of generating a new innovation, since their knowledge bases are now more equal. On the other hand, a repeated interaction is connected with lower uncertainty and makes it easier for each partner to anticipate the behaviour of the other, i.e. interaction is becoming easier, which increases the probability of success.

It is possible to introduce a spatial perspective in the Cowan, et al. (2006) model. In the original model, interaction during an earlier period is the only factor that reduces the uncertainty of 
actors concerning the failure risk of any interaction. Spatial proximity between actors is another factor that probably tend to reduce the uncertainties among actors about if other actors can be trusted or not. It enables the diffusion of information about the reliability of actors that are potential interaction partners and increases the possibility of sanctions in case of disloyal behaviour. Thus, we can assume that actors have a higher probability to establish links with other actors nearby, ceteris paribus. Spatial proximity may even be a substitute for cognitive, technological and/or organizational proximity in order to increase the probability of a successful interaction and cooperation (Autant-Bernard et al. 2012).

The perhaps most important conclusion of the above discussion is that when actors self-organize and establish links and networks, these networks tends according to theoretical models to be 'small world' networks. From a spatial perspective this implies that self-organised networks mainly tend to develop at the level of localities even if of course some of the links can be to actors in other localities. We now turn to a discussion about the formation and characteristics of social networks that due to their character and dependence of face-to-face interactions naturally are 'small world' networks.

\subsection{Social networks}

We start our discussion of social networks by defining and delineating three types of networks for individuals that are working either as employees or as self-employed as follows: ${ }^{1}$

- An individual's private network is his/her links to other individuals in the (extended) family, friends and other acquaintances, i.e. the links representing expressive relations(Lincoln and Miller 1979). We here focus on those private links that can be utilized for economic purposes.

- The business/work networks of an individual are here interpreted as the instrumental links (Lincoln and Miller 1979) an individual have to other individuals. These links can be limited to other people working at the same workplace but for many individuals the network also includes links to other individuals representing actual and potential customers and suppliers, where the supplier group not only includes links to suppliers of inputs in the form of goods and services but also links to providers of all kinds of business services including financial services but also other individuals representing various public administration organizations.

- Professional networks, lastly, are instrumental links mainly related to an individual's education, occupation and/or work tasks and includes links to individuals within occupational associations, trade unions, communities of practice, chambers of commerce, employers' associations, Rotary, etc.

If we add an individual's links in all these three networks together, we can talk about his/her social network. The social network allows an individual to draw on the information, knowledge, expertise, contacts and resources of other individuals and also get help and support from them (Burt 1992). Such a network represents an individual's social capital, i.e. the

\footnotetext{
${ }^{1}$ Of course, an individual can have a link to another person trough more than one network.
} 
actual and potential resources embedded within, available through and derived from the network of relations possessed by an individual (Coleman 1988; Uzzi 1996; Nahapiet and Ghoshal 1998). A critical factor of social networks is their density, since the density of social network links influence what kind of interactions, activities and transactions are made (Granovetter 1985). Individuals embedded in social networks can take advantage of very slowly changing institutional factors (Nyström 2012), such as a bounded solidarity, shared norms and values, common frameworks of reference, cultural rules, reciprocity, and enforceable trust that potentially function as a kind of social capital.

Embeddedness implies that social relations affect and shape the behaviour of the individuals in the network (Iandoli et al. 2014). It also implies that these individuals can safeguard their exchanges of information and knowledge and other resources as well as newly created knowledge and thus avoid the 'information paradox' (Arrow 1962) without using formal contracts (Jones et al. 1997). Social capital is here conceived as a system of shared values and beliefs that can prevent opportunistic behaviour by favouring trust building and cooperation among people (Putnam et al. 1993). The social network perspective emphasizes the cultural and institutional bases of the relationships between individuals (Granovetter 1985; Powell 1991).

Social networks provide information channels that are important sources of information and knowledge, since information and knowledge can flow relatively easy through such networks (Borgatti and Halgin 2011). Actually, it is a key characteristic of social networks that they involve privileged access to information and knowledge resources for the individuals in the network (Podolny and Page 1998) - information and knowledge that have been sorted and evaluated, so-called buzz (Bathelt et al. 2004). Empirical studies based upon the 'connections' model' show that the links between actors are the basis for information and knowledge externalities and that information and knowledge flows from one actor to another decrease substantially when the distance within the network between two actors increases (Singh 2005; Breschi and Lissoni 2006a).

For social networks as sources of information and knowledge it is important to consider that there are benefits from more diverse or "non-redundant" networks (Granovetter 1973). Thus, given that there are limits to the number of links that an individual can realistically establish and maintain, there is an information and knowledge advantage in a more diverse, less redundant social network in which the nodes to which an individual has links are not also connected to each other (Uzzi and Spiro 2005). Notions of the value of different links are also reflected in the distinction between weak and strong ties, whereby strong links are seen as more useful for help, support, and collaboration, whereas weak links are more useful as information and knowledge sources of creativity and innovation (Granovetter 1973; Burt 1992).

Social networks mainly tend to be geographically bounded, since the build-up and maintenance of personal links is strongly dependent upon frequent face-to-face interactions, and locational proximity reduces the costs and increases the frequency of personal contacts, which serve to build and to strengthen the social relations between the individuals in social networks (Dorfman 1987; Saxenian 1990; Almeida and Kogut 1997; Zucker et al. 1998) that also can 
be used for learning purposes (Almeida and Phene 2012). Breschi and Lissoni (2006b) show that the networks od interpersonal relations, which are the main vector for knowledge flows, appear to be concentrated locally. Thus, the interaction between the different individuals in a social network among other things is a function of the available material regional transport infrastructure, the functioning of the existing regional transport systems and the regional supply or arenas for meetings and interaction (Button et al. 1998; Karlsson and Manduchi 2001), i.e. a function of the regional factors that determine the foundations for regional accessibility and thus proximity. Certainly, some links can be long-distance but most links in these networks are due to the tyranny of distance short-distance links and regional proximity enhances the development of more complex social networks including common institutional and professional links (Graham 1985; Saxenian 1990; Almeida and Kogut 1999). Actually, research indicates the importance of geographically clustered social networks for the informal diffusion of information and knowledge (Rogers and Larsen 1984).

Links in social networks can be direct, i.e. an individual has a direct relationship to another individual or organization, or indirect, i.e. an individual has an indirect relationship to a third individual or organization via another individual or organization. An individual uses his/her network links to initiate and develop social relationships, to gather and to diffuse information and knowledge, etc. Individuals that are employed use their network links to interact with other people at the workplace, with customers and suppliers, with external people with similar interests, educations, occupations and work tasks, etc.

If we can turn to the mechanisms behind the formation of network links, we can point at education, common interests, living in the same neighbourhood and work, where the work links include both individuals at the same workplace and individuals at other work places within the same organization or at other organizations. Since we here are dealing with social links, i.e. links between individuals, it implies that the formation of links demand at least one personal meeting face-to-face. ${ }^{2}$ Thus, link activities (formation, maintenance and dissolution of links) are a function of the characteristics of individuals and their spatial behaviour, and of the spatial milieus where they are active. Personal link activities are generally driven by individual's personal preferences. This implies that there is a tendency among individuals to connect with other individuals that are similar in different respects, which reduced the potential access to new information and knowledge through such links (McPherson et al. 2001). This implies that it probably is the business and professional links in an individual's social network, i.e. the instrumental links that are developed via employment and/or self-employment that potentially will provide most new information and knowledge.

In this section, we have illustrated that social networks play a critical role for the diffusion of information and, in particular, knowledge. The information and knowledge that a person possess is function of how well developed his/her social networks is and, in particular, how rich his/her instrumental links are, since the instrumental links can be expected to provide more varied information and knowledge than the expressive links in the private part of the social network. In the following section, we discuss the set of links in a person's network that we

\footnotetext{
${ }^{2}$ Certainly, people can develop links via social media but here we assume that it is links formatted through faceto-face meetings that are the critical links for entrepreneurship.
} 
expect provide information and knowledge of special importance for a person's decision to become entrepreneur, namely direct and indirect links to entrepreneurs and managers. We use the term "entrepreneurship" networks for this set of links in a person's social network.

\section{3 "Entrepreneurship" networks}

We are now in a position to start a discussion about what links that are most critical for a person's decision to become an entrepreneur. Thus, we are interested in testing the importance of one particular type of (potential) network for the decision to become an entrepreneur, namely the accessibility to existing entrepreneurs and managers, i.e. to people that are self-employed or managers of a firm in a locality. We call such networks "entrepreneurship" networks. Individuals that work and live in the same community are exposed to one such network, while people that commutes are exposed to two such networks, one in the "work" locality and one in the "home" locality. Some individuals have both direct and indirect links to entrepreneurs and/or managers, while other people might only have indirect links. Of course, some of the links might represent participation in formal networks (Lawton Smith and Romeo 2013).

Since in modern economies each individual by necessity only has incomplete and scattered information and knowledge on any subject, we assume that "entrepreneurship" networks and in particular their density measured in terms of accessibility play a critical role i) in helping individuals in discovering, evaluating and exploit entrepreneurial opportunities (Dow and Zolnik 2012), and ii) in influencing the decisions of individuals actually to become entrepreneurs. Thus, most problems including entrepreneurial problems must be solved by processes of mutual interactive learning and for such learning to take place a potential entrepreneur is dependent upon the quality and the density of his/her "entrepreneurship" network. Actually the characteristics of "entrepreneurship" networks are determined by five factors (Cappelin 2003): i) the information, knowledge, experience and competence accumulated in each node, i.e. individual, ii) the travel time distance between the different nodes, i.e., individuals, in the network, iii) the connectivity to other interacting networks, iv) the speed of change of the links and the creation and destruction of links, and v) the overall trajectory of the structure of the network.

"Entrepreneurship" networks are critical because they provide role models for potential entrepreneurs and offer general and professional encouragement and acceptance of entrepreneurial endeavours as well as an environment conducive to entrepreneurial activities and the denser the network the larger the stimuli for entrepreneurial activities. The density of "entrepreneurship" networks is critical also from other aspects, since denser networks i) imply a richer set of information and knowledge corridors and processes that can channel information and knowledge to potential entrepreneurs (Shane 2000; Baker et al. 2005), ii) facilitate the integration of multi-disciplinary knowledge that is tacit and therefore embodied in people, and iii) allow for the rapid decision-making needed to cope with uncertainty (Patel and Pavitt 1991). This effect might be very important since it has been suggested that differences in entrepreneurial behaviour may be caused by information and knowledge asymmetries across potential entrepreneurs (Hayek 1945; Kirzner 1973). 
Denser "entrepreneurship" networks, i.e., "entrepreneurship" networks in localities where entrepreneurs and managers have clustered spatially, in principle offer better conditions for personal contacts and social and professional interactions between on the one side potential entrepreneurs and on the other side active and retired entrepreneurs and managers. These contacts and interactions may over time develop mutual trust among the actors and reduce the costs of interaction, the transfer of information and knowledge, cooperation, and even doing business (Goldstein and Gronberg 1984). We may assume that the potential for such proximity effects are larger, the denser the "entrepreneurship" network (Love and Roper 2001).

Actually, the available empirical evidences on cross-locality differences in various outcomes seem to be difficult to explain without human capital in account as well as the tendency for information and knowledge to spillover between individuals through face-to-face interaction (Gennaioli et al. 2013). In the current case, we can say that the spillovers of information and knowledge relevant for entrepreneurial actions through "entrepreneurship" networks generate entrepreneurship externalities, which are greater, the denser the "entrepreneurship" network. Our assumption about the critical role of the density of "entrepreneurship" networks is based upon the results of several empirical studies, which have found that information and knowledge spillovers tend to be greater in localities with a higher population and industrial density (Brunello and De Paola 2004; Audretsch and Lehmann 2005; Audretsch and Keilbach 2007). There is no reason what so ever to assume that other conditions should apply for entrepreneurship-relevant information and knowledge.

We assume that "entrepreneurship" externalities are a product of spontaneous meetings between people with complementary sets of skills, know-how and experiences relevant for entrepreneurship (Glaeser 1999). Due to the tyranny of distance most social, business and professional interactions take place rather close either to the place of residence or to the place of work, since the probability of them taking place depreciates with distance. This implies that entrepreneurial learning to a high extent is localised to the place of residence or the place of work (Rosenthal and Strange 2008). This implies that localities with dense "entrepreneurial" networks have a comparative advantage in the sense that they offer more opportunities for entrepreneurial interactions and learning within the time budgets of individuals.

The extent to which entrepreneurial learning takes place is, among other things, a function of the absorptive capacity of individuals, i.e. of their complementary skills and knowledge sets and of their ability to internalize entrepreneurial information and knowledge and to use it for commercial ends (Cohen and Levinthal 1990). It is also a function of the cognitive distance between people and the larger distance the higher the dynamic transaction costs (Langlois 1992), and thus the higher the costs of learning from and persuading, negotiating and coordinating with others. This, in particular, affects potential entrepreneurs, who have limited financial and time resources to bear such costs. We assume here that differences in the density of "entrepreneurial" networks between localities generate significant spatial differences in the accessibility to critical entrepreneurial information and knowledge, which might explain differences between localities in the rate of entrepreneurship. 
Interactions in "entrepreneurial" networks play a role when the peer group (Scheinkman 2008) affects the actions of potential entrepreneurs. It seems to be well established in the literature that influences from "entrepreneurial" networks often are critical in inducing individuals to consider an entrepreneurial career by providing entrepreneurial role models and in smoothing the start-up process for potential entrepreneurs as well as for running a new firm with a profit (Andersson and Larsson 2013). It is well known that a person that have entrepreneurs in the family or who knows entrepreneurs personally have a higher propensity to consider a career as an entrepreneur. In addition, active entrepreneurs and managers might have identified possible entrepreneurial ventures that they themselves for different reasons are not interested in pursuing and might be willing to transfer their business idea to other people within the "entrepreneurship" network that they think has the potential to become good entrepreneurs. Furthermore, people living and/or working in localities with dense "entrepreneurial" networks might be induced to become entrepreneurs seeing the examples set by others or they might feel forced to become entrepreneurs to become socially accepted. In both cases, this can be interpreted as that they demand a lower risk premium or lower discount factor than people living and/or working in localities with less dense "entrepreneurial" networks.

"Entrepreneurial" networks may provide information and advice that reduce the start-up costs of new firms. This is true for all the processes that a potential entrepreneur has to go through before starting a firm, such as product development, market intelligence and marketing, creating the firm as a legal entity, finding and renting facilities and equipment, hiring employees, and setting up an accounting system. The "entrepreneurial" network may also help in finding the necessary financial resources. A potential entrepreneur who via links in an "entrepreneurial" network is known by potential financiers might easier get access to financing, since being part of such a network reduce the problem with asymmetric information. Potential entrepreneurs with embedded relationships and links in an "entrepreneurial" network are more likely to get seed money and long-term financing (Uzzi 1999; Porter 2000; Gompers and Lerner 2001). Being linked into an "entrepreneurial" network may also help potential and new entrepreneurs in identifying customers and markets with the necessary purchasing power, organizing production and distribution at reasonable costs, and thus contribute to a newly started firm reaching break-even within a shorter time horizon.

Potential entrepreneurs that live and work in the same locality can take advantage of the "entrepreneurial" network in that locality. Potential entrepreneurs who commute can take advantage of the "entrepreneurial" network in both their "home" locality and their "work" locality. The aim of this paper is to test which of these two "entrepreneurial" networks, which is most important for those potential entrepreneurs who decide to become entrepreneurs, i.e. to start an new firm. Our hypothesis is that "entrepreneurial" externalities develop in close proximity to the place of work (Jacobs 1969). The motivation for this hypothesis is that that it is in the work situation that people mainly are able to observe and get in contact with active entrepreneurs and managers, and thus to develop those diversified instrumental links that might provide role models as well as the information and knowledge necessary to take the decision to become self-employed. 
An alternative hypothesis could be that "entrepreneurial" externalities develop in close proximity to the place of living, not least since there normally exist a strong segregation in housing areas and that entrepreneurs and managers tend to live in localities and neighbourhoods where many entrepreneurs and managers live. However, we assume that the links and contacts coupled to the place of living are less business oriented and more having to do with having children in the same school, attending the same church, being members of the same golf and boat clubs, etc. and thus more related to spare time activities than to business-related activities, i.e. we can expect that a high share of the links people have in the locality where they live to be expressive links.

Ideally, we would like to be able to follow the life story of different individuals in detail but that is seldom possible for large groups of people. By controlling for a number of background factors of individuals we might come some way to control for some important differences in life stories. Here we do something much simpler, we identify a number of groups of individuals that behave differently in the labour market. Actually, we identify three different groups: i) those who work and live in the same locality, ii) those who work in one locality but live in another locality in the same commuting region, and iii) those who work in a locality in one labour market region and live in a locality in another labour market region. The basic hypothesis is that individuals develop one type of links in the locality where they live and another type of links in the locality where they live. By this approach we are able to test this hypothesis, since we for the two last groups in the econometric tests can include the characteristics of both the work locality and the "home" locality and how these characteristics influence potential network formation.

Unfortunately, we are not able to identify directly the relevant peer groups (Scheinkman 2008) or to directly observe the links of different potential entrepreneurs, which implies that we are forced to use proxy variables. We assume that that the intra-locality accessibility to self-employed people can be used as an indicator of the density of the "entrepreneurial" networks that potential entrepreneurs can access. For people that commute we get one measure for their "work" locality and one measure for their "home" locality.

In this section we have highlighted the strategic role that "entrepreneurship" networks have for individuals' decisions to become self-employed. We have also presented our main hypothesis that it is the "entrepreneurship" networks related to place of work and not the "entrepreneurship" networks related to place of living that are the critical networks for the decision to become self-employed.

\section{Empirical design}

To test the influence from the home versus the work environment for an individual in his/her decision to become self-employed we first need to identify the type of commuting (or not) that an individual does. In order for us to accomplish this we use a detailed dataset provided by Statistics Sweden. In this dataset it is possible to get detailed information about individual characteristics such as gender, age, education, and ethnicity. It is also possible to match each individual to his/her working place. Most important for this paper is that it is also possible to 
distinguish between the location of residence and work. Hence, we can identify those that do not commute, i.e. those that live and work in the same municipality. Among those that commute, i.e. they do not live in the same municipality as they work, we can distinguish those that commute within the same functional region and those that commute outside the functional region. A functional region is such that is built up by several municipalities which together create a common labour market region. Hence, the intra-regional commuting is higher than inter-regional commuting. As functional regions are constructed to have a high intra-regional commuting the travel distance within the functional region is often around 45 to 60 minutes which gives a guideline on the difference between those that commute within the functional region and those that commute outside the functional region. Thus, we differentiate among three groups of individuals: 1) non-commuters (liv and work in the same municipality), 2) short-distance commuters (within the same functional region), and 3) longdistance commuters (outside the own functional region). Most individuals live and work in the same municipality and above 90 per cent live and work in the same region. The figures are even higher for those that are self-employed where over 95 per cent live and work in the same region. The reasoning behind this split is to see how different economic environments influence an individual's decision in becoming self-employed. Hence, the dependent variable is the change in employment status from those that were previously employed in 2007 to becoming self-employed in 2008. These are individuals that the year before received the majority of their income from an employee and the year after received the majority of their income from being self-employed.

The focus in this paper is on the economic environment characterized by the municipality and the functional region. Even though we differentiate between the home and residence municipality we use the same variable to describe them. Starting with the network effect, we proxy this by measuring the number of individuals in the municipality that are classified as being self-employed combined with the interaction cost, measured as the average travel distance by car within the municipality between different postcode areas (Network, municipality). The same principle can also be applied to the regional level where the network effect is captured by the number of self-employed in the same functional region but outside the own municipality (Network, region). Hence, the network effect is captured by accessibility measures presented in Equation 1 and 2, following Johansson et al. (2002; 2003).

Network, municipality $=\exp \left\{-\lambda_{0} t_{s s}\right\} N$

Network, region $=\sum_{v \in R, v \neq s} \exp \left\{-\lambda_{1} t_{s v}\right\} N$

Where $t_{s s}$ and $t_{s v}$ are travel time by car within or between municipalities, respectively. $N$ is the number of self-employed individuals in a municipality. $\lambda_{0}$ and $\lambda_{1}$ indicate the specific time-sensitivity parameter of commuting which differ for municipal versus regional commuting. To control for other municipal characteristics we use dummy variables, representing the type of region that the municipality belongs to. The following four categories are used: (1) Metropolitan functional regions, (2) Central municipalities, (3) Peripheral municipalities in larger functional regions, and (4) Peripheral municipalities in small 
functional regions. ${ }^{3}$ The characteristics of the regional types along the urban-rural hierarchy follow the same order where metropolitan functional regions are the most urban and peripheral municipalities in small functional regions are the most rural.

Even though the regional environment is in focus individual characteristics cannot be ignore. Characteristics that the individual is unable to influence, such as the gender (Gender) and foreign background (Background), is mentioned in numerous studies as important determinants of self-employment where men and immigrants are more likely to become selfemployed (Blanchflower 2000; Hout and Rosen 2000). The human capital of the individual is also influencing the choice of becoming self-employed (Parker 2004). We define human capital in a broad sense and capture it by the number of schooling years (Education), the type of education (Education type), number of years after finishing school (Experience) and the type of task the individual performed in the last period before becoming self-employed (Occupation). Connected to the level of experience, in terms of number of years, is previous experience being self-employed (Self-employed experience). Previous studies confirm that there is a positive relationship between previous experience of self-employment and current decisions of being self-employed and also the success of the self-employed (Carroll and Mosakowski 1987; Taylor 1999; Sena et al. 2012). At the individual level we also test for different factors that tell us something about the economic environment. The first one is a variable that controls for if the individual have lived in the same municipality for the last five years (Stayer). This variable is included to see if the local knowledge about the economic environment is important in the decision of becoming self-employed. Connected to the commuter versus non-commuter we can observe if the individual have commuted in the past (Past commuter) how long the individual has been a commuter over the last ten years (Years of commuting). It is not only of interest if an individual has commuted or not but where the individual choose to commute. Here we distinguish if an individual has commuted up or down the urban-rural hierarchy (Commuter, urban). Sweden's municipalities are in this case defined either as central municipality or a peripheral municipality. Central municipalities are the largest municipality within each functional region.

The final set of control variables are at the establishment level where we control for the industry (Industry) as different industries tend to have different levels of self-employment (Bates 1995; Hammond and Gurley-Calvez 2012). The size of the establishment have also been proven to influence the self-employment propensity (Establishment size) where individuals working in small establishments often have a higher tendency to become selfemployed (Blanchflower and Meyer 1994). The variables used in the empirical estimations are presented in table 1 along with the summary statistics.

Table 1. Description of variables and summary statistics ( $\mathrm{N}=3180884)$

\begin{tabular}{|c|c|c|c|}
\hline Description & Exp.sign & Mean & St. dev \\
\hline \multicolumn{4}{|l|}{ Dependent variable } \\
\hline Change in employment status between 2007 and 2008, 1=self-employed in & & 0.065 & 0.246 \\
\hline
\end{tabular}




\begin{tabular}{|c|c|c|c|c|}
\hline \multicolumn{2}{|l|}{2008 and employed in $2007,0=$ otherwise } & & & \\
\hline \multicolumn{5}{|c|}{ Independent variable (all variables are measured in 2007) } \\
\hline \multicolumn{5}{|l|}{ Individual level } \\
\hline $\begin{array}{l}\text { Age of individual-6-number of schooling } \\
\text { years }\end{array}$ & Experience & + & 26.541 & 12.380 \\
\hline Experience square & Experience $^{2}$ & - & 857.726 & 669.463 \\
\hline Number of schooling years & Education & $+/-$ & 12.389 & 2.353 \\
\hline $\begin{array}{l}\text { Categorization of different educational tracks } \\
\text { (15 in total) }\end{array}$ & Education type & & & \\
\hline $\begin{array}{l}\text { Categorization of different occupations ( } 4 \text { in } \\
\text { total, cognitive occupations, occupations in } \\
\text { management and administration, social } \\
\text { occupations, and standardized occupations) }{ }^{\mathrm{a}}\end{array}$ & Occupation & & & \\
\hline Dummy, $1=$ male, $0=$ female & Gender & + & 0.526 & 0.499 \\
\hline Dummy, 1=born in Sweden, 0=otherwise & Background & + & 0.114 & 0.317 \\
\hline $\begin{array}{l}\text { Dummy, } 1=\text { Lived in the same municipality } \\
\text { for the last five years, } 0=\text { otherwise }\end{array}$ & Stayer & + & 0.832 & 0.374 \\
\hline $\begin{array}{l}\text { Dummy, } 1=\text { Commuted in any of the last ten } \\
\text { years, } 0=\text { otherwise }\end{array}$ & Past commuter & + & 0.542 & 0.498 \\
\hline $\begin{array}{l}\text { How many years the individual have } \\
\text { commuted over the last ten years }\end{array}$ & Years of commuting & + & 2.835 & 3.414 \\
\hline $\begin{array}{l}\text { Dummy, } 1=\text { Commuted to a more urban } \\
\text { municipality, } 0=\text { otherwise }\end{array}$ & Commuter, urban & + & 0.149 & 0.356 \\
\hline \multicolumn{5}{|l|}{ Establishment level(at previous workplace) } \\
\hline $\begin{array}{l}\text { Categorization of different industries (based } \\
\text { at the two-digit level, } 55 \text { in total) }\end{array}$ & Industry & & & \\
\hline Number of employees & Establishment size & - & 9.357 & 59.841 \\
\hline \multicolumn{5}{|l|}{ Municipality level } \\
\hline $\begin{array}{l}\text { Access to self-employed in the same } \\
\text { municipality }\end{array}$ & Network municipality & + & 732.503 & 1226.367 \\
\hline Regional category & $\begin{array}{l}\text { Dummy, (1) Metropolitan } \\
\text { functional regions, (2) } \\
\text { Central municipalities, (3) } \\
\text { Peripheral municipalities } \\
\text { in larger functional } \\
\text { regions, and (4) Peripheral } \\
\text { municipalities in small } \\
\text { functional regions (base) }\end{array}$ & & & \\
\hline \multicolumn{5}{|l|}{ Region level } \\
\hline Access to self-employed in the same region ${ }^{b}$ & Network region & + & 2153.949 & 3626.864 \\
\hline
\end{tabular}

\subsection{Empirical results}

To capture the importance of networks we split the sample of individuals according to two characteristics (i) the type of occupation where we distinguish among four different types: cognitive occupations, occupations in management and administration, social occupations, and standardized occupations, and (ii) education attainment where we distinguish among three levels: up to secondary high school, between secondary and bachelor degree, and three of more years of higher education. The categorisation also builds on the findings from previous studies that claim that self-employment is a non-linear function of education where individuals with low and high levels often show higher propensity to become self-employed (Blanchflower 2000). We start by presenting the results for those individuals that live and 
work in the same municipality, i.e. non-commuters, for the four occupation categories and three educational levels. Here we control for if they commuted in the past and how this influence the probability to become self-employed. As the dependent variable is binary, we investigate the relationship by using a logit function. All results are presented in odds ratio with a lower bound of zero. Hence, an estimated value above one indicate a positive relationship and an estimated value below one indicates a negative relationship between the investigated variables.

Table 2. Determinants of self-employment for individuals that live and work in the same municipality (work=live), different occupations and education levels, logit

Dependent variable: Change in employment status between 2007 and 2008, 1=self-employed in 2008 and employed in 2007, $0=$ otherwise

\begin{tabular}{|c|c|c|c|c|c|c|c|}
\hline & \multicolumn{4}{|c|}{ Type of occupation } & \multicolumn{3}{|l|}{ Education level } \\
\hline & $\begin{array}{l}\text { Cognitive } \\
\text { occupations }\end{array}$ & $\begin{array}{l}\text { Occupations in } \\
\text { management and } \\
\text { administration }\end{array}$ & $\begin{array}{l}\text { Social } \\
\text { occupations }\end{array}$ & $\begin{array}{l}\text { Standardized } \\
\text { occupations }\end{array}$ & $\begin{array}{l}\text { Up to secondary } \\
\text { high school }\end{array}$ & $\begin{array}{l}\text { Between } \\
\text { secondary and } \\
\text { bachelor degree }\end{array}$ & $\begin{array}{l}\text { Three of more } \\
\text { years of higher } \\
\text { education }\end{array}$ \\
\hline \multicolumn{8}{|c|}{ Individual level } \\
\hline Experience & $\begin{array}{l}1.025 * * \\
(0.001)\end{array}$ & $\begin{array}{l}1.028 * * \\
(0.001)\end{array}$ & $\begin{array}{l}1.027 * * \\
(0.001)\end{array}$ & $\begin{array}{l}1.030 * * \\
(0.001)\end{array}$ & $\begin{array}{l}1.028 * * \\
(0.001)\end{array}$ & $\begin{array}{l}1.021 * * \\
(0.001)\end{array}$ & $\begin{array}{l}1.026 * * \\
(0.002)\end{array}$ \\
\hline Experience $^{2}$ & $\begin{array}{l}0.999 * * \\
(0.0001)\end{array}$ & $\begin{array}{l}0.998 * * \\
(0.0001)\end{array}$ & $\begin{array}{l}0.999 * * \\
(0.0001) \\
\end{array}$ & $\begin{array}{l}0.999 * * \\
(0.0001)\end{array}$ & $\begin{array}{l}0.999 * * \\
(0.0001)\end{array}$ & $\begin{array}{l}0.998 * * \\
(0.0001)\end{array}$ & $\begin{array}{l}0.998 * * \\
(0.0002) \\
\end{array}$ \\
\hline Education & $\begin{array}{l}1.045^{* *} \\
(0.010)\end{array}$ & $\begin{array}{c}0.997 \\
(0.004)\end{array}$ & $\begin{array}{l}1.053 * * \\
(0.007)\end{array}$ & $\begin{array}{l}1.016 * \\
(0.007)\end{array}$ & - & - & - \\
\hline Gender & $\begin{array}{l}1.744 * * \\
(0.056)\end{array}$ & $\begin{array}{l}3.110 * * \\
(0.100)\end{array}$ & $\begin{array}{c}2.256 * * \\
(0.091)\end{array}$ & $\begin{array}{l}1.607 * * \\
(0.042)\end{array}$ & $\begin{array}{c}2.754 * * \\
(0.076)\end{array}$ & $\begin{array}{l}1.952 * * \\
(0.052)\end{array}$ & $\begin{array}{l}1.747 * * \\
(0.069)\end{array}$ \\
\hline Background & $\begin{array}{c}0.914 * * \\
(0.037)\end{array}$ & $\begin{array}{c}0.969 \\
(0.022) \\
\end{array}$ & $\begin{array}{l}1.078 * * \\
(0.032)\end{array}$ & $\begin{array}{c}0.825 * * \\
(0.023)\end{array}$ & $\begin{array}{c}0.918 * * \\
(0.017)\end{array}$ & $\begin{array}{c}1.014 \\
(0.034) \\
\end{array}$ & $\begin{array}{l}0.881 * * \\
(0.032)\end{array}$ \\
\hline Stayer & $\begin{array}{c}0.868 * * \\
(0.024)\end{array}$ & $\begin{array}{c}0.858 * * \\
(0.022)\end{array}$ & $\begin{array}{c}1.012 \\
(0.027) \\
\end{array}$ & $\begin{array}{l}0.945^{*} \\
(0.027)\end{array}$ & $\begin{array}{l}0.902 * * \\
(0.016)\end{array}$ & $\begin{array}{l}0.916 * * \\
(0.023)\end{array}$ & $\begin{array}{l}0.937 * * \\
(0.029)\end{array}$ \\
\hline Past commuter & $\begin{array}{c}0.870 * * \\
(0.031)\end{array}$ & $\begin{array}{c}0.736 * * \\
(0.019)\end{array}$ & $\begin{array}{c}0.763 * * \\
(0.022)\end{array}$ & $\begin{array}{c}0.733 * * \\
(0.017)\end{array}$ & $\begin{array}{c}0.731 * * \\
(0.013)\end{array}$ & $\begin{array}{c}0.875 * * \\
(0.023)\end{array}$ & $\begin{array}{c}0.839 * * \\
(0.045)\end{array}$ \\
\hline Occupation type & $\mathrm{NO}$ & $\mathrm{NO}$ & $\mathrm{NO}$ & $\mathrm{NO}$ & $Y E S$ & $Y E S$ & $Y E S$ \\
\hline $\begin{array}{l}\text { Establishment } \\
\text { size }\end{array}$ & $\begin{array}{c}0.265 * * \\
(0.014)\end{array}$ & $\begin{array}{c}0.347 * * \\
(0.003)\end{array}$ & $\begin{array}{c}0.198 * * \\
(0.002)\end{array}$ & $\begin{array}{c}0.212 * * \\
(0.002)\end{array}$ & $\begin{array}{c}0.246 * * \\
(0.002)\end{array}$ & $\begin{array}{c}0.259 * * \\
(0.005)\end{array}$ & $\begin{array}{c}0.307 * * \\
(0.018)\end{array}$ \\
\hline \multicolumn{8}{|c|}{ Economic environment } \\
\hline $\begin{array}{l}\text { Network mu- } \\
\text { nicipality }\end{array}$ & $\begin{array}{c}0.967 * * \\
(0.013)\end{array}$ & $\begin{array}{c}0.890 * * \\
(0.012)\end{array}$ & $\begin{array}{c}0.948 * * \\
(0.013)\end{array}$ & $\begin{array}{c}0.923 * * \\
(0.014)\end{array}$ & $\begin{array}{c}0.921 * * \\
(0.011)\end{array}$ & $\begin{array}{c}0.937 * * \\
(0.012)\end{array}$ & $\begin{array}{c}0.968 \\
(0.019) \\
\end{array}$ \\
\hline Network region & $\begin{array}{l}1.145 * * \\
(0.021)\end{array}$ & $\begin{array}{c}1.141 * * \\
(0.019)\end{array}$ & $\begin{array}{l}1.069 * * \\
(0.012)\end{array}$ & $\begin{array}{c}1.096 * * \\
(0.016)\end{array}$ & $\begin{array}{c}1.108 * * \\
(0.013)\end{array}$ & $\begin{array}{l}1.134 * * \\
(0.024)\end{array}$ & $\begin{array}{l}1.129 * * \\
(0.024)\end{array}$ \\
\hline$N$ & 416225 & 420806 & 666786 & 604055 & 1350087 & 561940 & 198070 \\
\hline Wald $c h i^{2}$ & 48651 & 62233 & 72848 & 78648 & 187688 & 37092 & 51506 \\
\hline Pseudo $R^{2}$ & 0.58 & 0.44 & 0.52 & 0.54 & 0.50 & 0.51 & 0.57 \\
\hline
\end{tabular}

** significant at 1 percent, *significant at 5 percent. Cluster (municipality) standard errors within parenthesis.

The empirical estimations control for educational type, regional type and industry of previous employer.

Focusing on the variable which describes the economic environment we observe that the access to other self-employed individuals in the municipality (Network municipality) are significant and negatively related to the probability of becoming self-employed. This holds for all occupational categories and educational levels except the highest level. The same variable but focusing on the regional level (Network region) is however positive and significant for all categories. The results indicate that at the more local level the access to 
other self-employed work as a discouraging factor which hampers the probability to become self-employed. This could be a reflection of a vast competition in the economic environment which the self-employed is going to be active in. On the other hand, having access to many other self-employed in the region is positive which indicate that the network building stretches beyond the direct surrounding environment. Also it might indicate that an selfemployed is reaching markets and customers beyond the municipal level. The network variables are correlated with the size of the municipality, why these are not performed in the same estimations. To capture the size of the municipality an dummy is included that captures different type of regions. When the same estimations however are performed using size variables (population density) these are not however perfect mirrors of the presented results here. Hence, the network variables are also capturing other aspects besides the pure size of a location.

Looking across the different occupational categories and educational levels there are only minor differences in how the network opportunities in the own municipality and the region influence the probability to become self-employed. The main difference is that the municipal network is insignificant for those individuals with the highest level (bachelor degree or more). Thus, there does not seem to be any differences in how different type of non-commuters (in the sense that they do not cross municipal borders) based on occupation and education are influenced by the network in the municipality nor in the region. Whether the individual have commuted in the past (Past commuter) is negatively associated with the tendency to become self-employed. Hence, this indicate that previous networks built up in other locations in the past does not push an individual to become self-employed, rather it is discouraging the individual.

The control variables are as expected and follow previous research. More experience, i.e. individuals with a higher age, are more likely to become self-employed even though there is a marginal decreasing effect. Another aspect of human capital is the level of education where years of schooling has a positive effect on become self-employed for all occupational groups except individuals with an occupations in management and administration. The effect from education is strongest for individuals with an cognitive or social occupation. Men irrespectively of occupational and education level have a higher tendency to become selfemployed. The background of an individual in terms of where he/she were born differs across occupational groups and across educational levels. In cognitive and standardized occupations foreign born have a lower tendency to become self-employed while those individuals with a foreign background working in a social occupation has a higher tendency to become selfemployed. Across educational levels individuals with a foreign background has a lower tendency to become self-employed for the lower and higher levels while it is insignificant for intermediate levels. The dummy that controls for if the individuals have been living in the same municipality over the last five years (Stayer) is negatively associated with becoming self-employed. This is contradicting to our statement on how network building ought to induce self-employment. Having worked in smaller establishments increases the likelihood to become self-employed. 
We continue our analysis by examining those that actual commute, live and work in different municipalities. These individuals commute within the same functional region, also here we divide the sample according to occupation categories and level of education. The results are presented in Table 3. Since the individual have access to different set of networks we analyse how the access to self-employed in the municipality where the individual lives differ from the municipality where the individual works. 
Table 3. Determinants of self-employment, individuals that live and work in different municipalities with the same region, occupation and education levels, logit. Dependent variable: Change in employment status between 2007 and 2008, 1=self-employed in 2008 and employed in 2007, 0=otherwise

\begin{tabular}{|c|c|c|c|c|c|c|c|c|c|c|c|c|c|c|}
\hline & \multicolumn{8}{|c|}{ Type of occupation } & \multicolumn{6}{|c|}{ Education level } \\
\hline & \multicolumn{2}{|c|}{$\begin{array}{l}\text { Cognitive } \\
\text { occupations }\end{array}$} & \multicolumn{2}{|c|}{$\begin{array}{l}\text { Occupations in } \\
\text { management and } \\
\text { administration }\end{array}$} & \multicolumn{2}{|c|}{ Social occupations } & \multicolumn{2}{|c|}{$\begin{array}{l}\text { Standardized } \\
\text { occupations }\end{array}$} & \multicolumn{2}{|c|}{$\begin{array}{l}\text { Up to secondary } \\
\text { high school }\end{array}$} & \multicolumn{2}{|c|}{$\begin{array}{l}\text { Between secondary } \\
\text { and bachelor degree }\end{array}$} & \multicolumn{2}{|c|}{$\begin{array}{l}\text { Three of more years of } \\
\text { higher education }\end{array}$} \\
\hline \multicolumn{15}{|l|}{ Individual level } \\
\hline Experience & \multicolumn{2}{|c|}{$\begin{array}{l}1.031 * * \\
(0.002)\end{array}$} & \multicolumn{2}{|c|}{$\begin{array}{l}1.031 * * \\
(0.002)\end{array}$} & \multicolumn{2}{|c|}{$\begin{array}{l}1.026 * * \\
(0.002) \\
\end{array}$} & \multicolumn{2}{|c|}{$\begin{array}{l}1.031 * * \\
(0.002)\end{array}$} & \multicolumn{2}{|c|}{$\begin{array}{l}1.029 * * \\
(0.002)\end{array}$} & \multicolumn{2}{|c|}{$\begin{array}{l}1.025 * * \\
(0.002)\end{array}$} & \multicolumn{2}{|c|}{$\begin{array}{l}1.031 * * \\
(0.002)\end{array}$} \\
\hline Experience $^{2}$ & \multicolumn{2}{|c|}{$\begin{array}{l}0.998^{* *} \\
(0.0001)\end{array}$} & \multicolumn{2}{|c|}{$\begin{array}{l}0.998 * * \\
(0.0001)\end{array}$} & \multicolumn{2}{|c|}{$\begin{array}{l}0.998 * * \\
(0.0001)\end{array}$} & \multicolumn{2}{|c|}{$\begin{array}{l}0.998 * * \\
(0.0001)\end{array}$} & \multicolumn{2}{|c|}{$\begin{array}{l}0.998 * * \\
(0.0001)\end{array}$} & \multicolumn{2}{|c|}{$\begin{array}{l}0.997 * * \\
(0.0001)\end{array}$} & \multicolumn{2}{|c|}{$\begin{array}{l}0.997 * * \\
(0.0003)\end{array}$} \\
\hline Education & \multicolumn{2}{|c|}{$\begin{array}{l}1.123 * * \\
(0.010)\end{array}$} & \multicolumn{2}{|c|}{$\begin{array}{l}0.964 * * \\
(0.008)\end{array}$} & \multicolumn{2}{|c|}{$\begin{array}{l}1.036^{* *} \\
(0.012)\end{array}$} & \multicolumn{2}{|c|}{$\begin{array}{l}1.122 * * \\
(0.016)\end{array}$} & \multicolumn{2}{|c|}{ 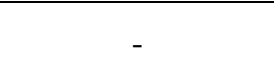 } & \multicolumn{2}{|c|}{-} & \multicolumn{2}{|c|}{ 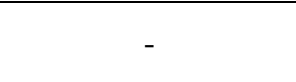 } \\
\hline Gender & \multicolumn{2}{|c|}{$\begin{array}{l}2.239 * * \\
(0.131)\end{array}$} & $\begin{array}{l}3.5 \\
(0 .\end{array}$ & $\begin{array}{l}72 * * \\
26)\end{array}$ & $\begin{array}{l}2.8 \\
(0 .\end{array}$ & $\begin{array}{l}9 * * \\
29)\end{array}$ & $\begin{array}{r}2.23 \\
(0.1\end{array}$ & & $\begin{array}{l}3.4 \\
(0 .\end{array}$ & & $\begin{array}{l}2.3 \\
(0 .\end{array}$ & $\begin{array}{l}6 * * \\
91)\end{array}$ & $\begin{array}{l}2.3 \\
(0 .\end{array}$ & \\
\hline Background & $\begin{array}{l}0.7 \\
(0 .\end{array}$ & $\begin{array}{l}7 * * \\
41) \\
\end{array}$ & $\begin{array}{l}0.8 \\
(0 .\end{array}$ & $\begin{array}{l}48 * * \\
29) \\
\end{array}$ & $\begin{array}{r}0 . \\
(0 .\end{array}$ & $\begin{array}{l}76 \\
42) \\
\end{array}$ & $\begin{array}{l}0.60 \\
(0.0\end{array}$ & & $\begin{array}{l}0.8 \\
(0 .\end{array}$ & $\begin{array}{l}2 * * \\
24)\end{array}$ & $\begin{array}{l}0.8 \\
(0 .\end{array}$ & $\begin{array}{l}* * \\
34)\end{array}$ & $\begin{array}{c}0.7 \\
(0 .\end{array}$ & \\
\hline Stayer & & $\begin{array}{l}62 \\
34) \\
\end{array}$ & $\begin{array}{l}0.8 \\
(0 .\end{array}$ & $\begin{array}{l}31 * * \\
39) \\
\end{array}$ & $\begin{array}{r}0 . \\
(0 . \\
\end{array}$ & $\begin{array}{l}46 \\
46)\end{array}$ & $\begin{array}{r}0.9 \\
(0.0 \\
\end{array}$ & & $\begin{array}{l}0.8 \\
(0 .\end{array}$ & $\begin{array}{l}6 * * \\
24) \\
\end{array}$ & $\begin{array}{l}0.8 \\
(0 .\end{array}$ & $\begin{array}{l}4 * * \\
37) \\
\end{array}$ & $\begin{array}{l}1.0 \\
(0 . \\
\end{array}$ & \\
\hline $\begin{array}{l}\text { Years of } \\
\text { commuting }\end{array}$ & $\begin{array}{l}1.0 \\
(0 .\end{array}$ & 17*) & $\begin{array}{l}1.0 \\
(0 .\end{array}$ & 53** & $\begin{array}{l}1.0 \\
(0 .\end{array}$ & 6** & $\begin{array}{l}1.05 \\
(0.0\end{array}$ & & $\begin{array}{l}1.0 \\
(0 .\end{array}$ & 12** & & $\begin{array}{l}35 \\
20)\end{array}$ & $\begin{array}{l}1.0 \\
(0 .\end{array}$ & \\
\hline $\begin{array}{l}\text { Commuter, } \\
\text { urban }\end{array}$ & & $\begin{array}{l}24 \\
46) \\
\end{array}$ & & 391 & $\begin{array}{r}0 . \\
(\mathbf{0} .\end{array}$ & $\begin{array}{l}88 \\
00)\end{array}$ & $\begin{array}{r}1.2 \\
(0.1\end{array}$ & & $\begin{aligned} 1 . \\
(0 .\end{aligned}$ & & & $\begin{array}{l}55 \\
93)\end{array}$ & $\begin{array}{l}1 . \\
(0 .\end{array}$ & \\
\hline Occupation & & & & $\mathrm{O}$ & & & $\mathrm{N}$ & & & & & & & \\
\hline $\begin{array}{l}\text { Establishment } \\
\text { size }\end{array}$ & $\begin{array}{l}0.3 \\
(0 .\end{array}$ & $\begin{array}{l}1 * * \\
15)\end{array}$ & $\begin{array}{l}0.3 \\
(0 .\end{array}$ & $\begin{array}{l}31 * * \\
12)\end{array}$ & $\begin{array}{l}0.2 \\
(0 .\end{array}$ & $\begin{array}{l}2 * * \\
06)\end{array}$ & $\begin{array}{l}0.22 \\
(0.6\end{array}$ & & $\begin{array}{l}0.2 \\
(0 .\end{array}$ & $\begin{array}{l}0 * * \\
05)\end{array}$ & $\begin{array}{l}0.3 \\
(0 .\end{array}$ & $\begin{array}{l}2 * * \\
12)\end{array}$ & $\begin{array}{l}0.3 \\
(0 .\end{array}$ & \\
\hline Economic en & onment & & & & & & & & & & & & & \\
\hline & Work & Home & Work & Home & Work & Home & Work & Home & Work & Home & Work & Home & Work & Home \\
\hline $\begin{array}{l}\text { Network } \\
\text { municipality }\end{array}$ & $\begin{array}{c}1.135 * * \\
(0.021) \\
\end{array}$ & $\begin{array}{c}0.984 \\
(0.029) \\
\end{array}$ & $\begin{array}{c}1.020 \\
(0.019) \\
\end{array}$ & $\begin{array}{c}1.029 \\
(0.018) \\
\end{array}$ & $\begin{array}{l}1.062 * \\
(0.027) \\
\end{array}$ & $\begin{array}{l}1.006 \\
(0.021) \\
\end{array}$ & $\begin{array}{l}1.057 * * \\
(0.022)\end{array}$ & $\begin{array}{c}1.011 \\
(0.025) \\
\end{array}$ & $\begin{array}{l}1.029 * \\
(0.016) \\
\end{array}$ & \begin{tabular}{|c|}
1.016 \\
$(0.015)$ \\
\end{tabular} & $\begin{array}{c}1.093 * * \\
(0.019) \\
\end{array}$ & $\begin{array}{c}1.039 \\
(0.023) \\
\end{array}$ & $\begin{array}{c}1.113 * * \\
(0.020)\end{array}$ & $\begin{array}{c}0.978 \\
(0.033) \\
\end{array}$ \\
\hline $\begin{array}{l}\text { Network } \\
\text { region }\end{array}$ & $\begin{array}{l}1.1 \\
(0 .\end{array}$ & $\begin{array}{l}\text { 8** } \\
\text { 34) }\end{array}$ & $\begin{array}{l}1 . \\
(0 .\end{array}$ & 34 & $\begin{array}{l}0.9 \\
(0 .\end{array}$ & $\begin{array}{l}5 * * \\
23)\end{array}$ & $\begin{array}{r}1.0 \\
(0.0\end{array}$ & & $\begin{array}{l}1 . \\
(0 .\end{array}$ & & & $\begin{array}{l}18 \\
31)\end{array}$ & $\begin{array}{l}1 . \\
(0 .\end{array}$ & \\
\hline$N$ & 193 & 524 & 164 & 110 & 196 & 759 & 176 & & 433 & 292 & 20 & 128 & & \\
\hline Wald chi ${ }^{2}$ & & 283 & & 706 & & 567 & 19 & & 59 & & & & 28 & \\
\hline Pseudo $R^{2}$ & & & & 33 & & 40 & 0. & & 0 & & & & & \\
\hline
\end{tabular}

** significant at 1 percent, *significant at 5 percent. Cluster (municipality) standard errors within parenthesis. Control for educational, regional type and industry. 
When analysing those individuals that do commute over municipal borders but within the same functional region (short-distance commuters) we detect a slightly different pattern compared to the non-commuters. For those that commute, it is mainly the local environment where the individual work (Network municipality) that is positively associated with the probability to become self-employed. The network opportunities in the municipality where the individual lives does not have any effect on the tendency to become self-employed. The regional level (Network region) however is only positively associated for those with a cognitive occupation, it is insignificant for all other occupational types and educational levels. The exception is those with a social occupation where having access to self-employed in the region is negatively associated with becoming self-employed. Hence, for short-distance commuters it is the economic environment and the network opportunities in the work location that is important for becoming self-employed. In this case it is the local, municipal, access to self-employed that is influential. Individuals form business networks with colleagues, suppliers, customers, competitors etc. where they work and this is then possible used while forming the decision of becoming self-employed. The social network build on social activities in the home location is by no means unimportant but do not influence choice in becoming self-employed.

One could hypothesis that it is beneficial for individuals to commute to more urban locations (Commuter, urban) since these are characterised by a larger market and access to more people and more diversified set of individuals. As the number of interaction increases with the size of a location, locations higher up in the urban-rural dichotomy have an advantage in creating social and professional networks. Those individuals that do commute to more urban locations within the functional region are however not more or less likely to become self-employed as the dummy is insignificant. The length of the commuting in time (Years of commuting) is positively associated with becoming self-employed, this holds for all occupational types and educational levels except those with an intermediate level of education (between secondary and bachelor degree). This supports the notation that it takes some time to build up networks, in this case business networks, and as individuals get a stronger network they are also more likely to become self-employed.

The control variables overall do not alter for commuters compared to non-commuters (live and work in the same municipality). One difference is that individuals with more schooling and with a social occupation is less likely to become self-employed. Another difference is that the dummy indicating whether you have stayed in the same municipality for the last five years (Stayer) is only negatively associated with the probability to become self-employed for those in social occupations. For the other occupation types it is insignificant. Turning to the educational levels, we observe that for highly educated individuals having lived in the same municipality for the last five years increases the likelihood that the individual will become self-employed.

In the last scenario we observe those individuals that work and live in different functional regions. Hence, they are long-distance commuters as it normally takes at least 45 to 60 minutes to reach another functional region. The results are presented in Table 4. Similar to Table 3, we separate the access to self-employed in the municipality of residence and municipality of work and add the same at the region level, i.e. access to self-employed in the region where the individual live and where she/he works. 
Table 4. Determinants of self-employment for individuals that live and work in different regions, different occupations and education levels, logit. Dependent variable: Change in employment status between 2007 and 2008, 1=self-employed in 2008 and employed in 2007, 0=otherwise

\begin{tabular}{|c|c|c|c|c|c|c|c|c|c|c|c|c|c|c|}
\hline & \multicolumn{8}{|c|}{ Type of occupation } & \multicolumn{6}{|c|}{ Education level } \\
\hline & \multicolumn{2}{|c|}{ Cognitive occupations } & \multicolumn{2}{|c|}{$\begin{array}{l}\text { Occupations in } \\
\text { management and } \\
\text { administration }\end{array}$} & \multicolumn{2}{|c|}{ Social occupations } & \multicolumn{2}{|c|}{$\begin{array}{l}\text { Standardized } \\
\text { occupations }\end{array}$} & \multicolumn{2}{|c|}{$\begin{array}{l}\text { Up to secondary high } \\
\text { school }\end{array}$} & \multicolumn{2}{|c|}{$\begin{array}{l}\text { Between secondary } \\
\text { and bachelor degree }\end{array}$} & \multicolumn{2}{|c|}{$\begin{array}{l}\text { Three of more } \\
\text { years of higher } \\
\text { education }\end{array}$} \\
\hline \multicolumn{15}{|l|}{ Individual level } \\
\hline Experience & \multicolumn{2}{|c|}{$\begin{array}{l}1.019 * * \\
(0.004)\end{array}$} & \multicolumn{2}{|c|}{$\begin{array}{l}1.027 * * \\
(0.003)\end{array}$} & \multicolumn{2}{|c|}{$\begin{array}{l}1.025 * * \\
(0.003)\end{array}$} & \multicolumn{2}{|c|}{$\begin{array}{l}1.030 * * \\
(0.003)\end{array}$} & \multicolumn{2}{|c|}{$\begin{array}{l}1.028 * * \\
(0.002)\end{array}$} & \multicolumn{2}{|c|}{$\begin{array}{l}1.022 * * \\
(0.004)\end{array}$} & \multicolumn{2}{|c|}{$\begin{array}{l}1.019 * * \\
(0.005)\end{array}$} \\
\hline Experience $^{2}$ & \multicolumn{2}{|c|}{$\begin{array}{l}0.998 * * \\
(0.0001)\end{array}$} & \multicolumn{2}{|c|}{$\begin{array}{l}0.998 * * \\
(0.0001)\end{array}$} & \multicolumn{2}{|c|}{$\begin{array}{l}0.998 * * \\
(0.0001)\end{array}$} & \multicolumn{2}{|c|}{$\begin{array}{l}0.998 * * \\
(0.0001)\end{array}$} & \multicolumn{2}{|c|}{$\begin{array}{l}0.998 * * \\
(0.0001)\end{array}$} & \multicolumn{2}{|c|}{$\begin{array}{l}0.998 * * \\
(0.0001)\end{array}$} & \multicolumn{2}{|c|}{$\begin{array}{l}0.998 * * \\
(0.0001)\end{array}$} \\
\hline Education & \multicolumn{2}{|c|}{$\begin{array}{l}1.077 * * \\
(0.016)\end{array}$} & \multicolumn{2}{|c|}{$\begin{array}{l}0.938 * * \\
(0.013)\end{array}$} & \multicolumn{2}{|c|}{$\begin{array}{l}1.015 \\
(0.028)\end{array}$} & \multicolumn{2}{|c|}{$\begin{array}{l}1.174 * * \\
(0.035)\end{array}$} & \multicolumn{2}{|c|}{ 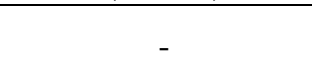 } & \multicolumn{2}{|c|}{ - } & \multicolumn{2}{|c|}{-} \\
\hline Gender & & & & $\begin{array}{l}0 * * \\
59)\end{array}$ & $\begin{array}{l}2.2 \\
(0\end{array}$ & $\begin{array}{l}76 * * \\
158)\end{array}$ & $\begin{array}{l}2.3 \\
(0 .\end{array}$ & $\begin{array}{l}1 * * \\
97)\end{array}$ & $\begin{array}{l}2.6 \\
(0\end{array}$ & & $\begin{array}{l}1.8 \\
(0\end{array}$ & $\begin{array}{l}59 * * \\
141)\end{array}$ & $\begin{array}{l}2.0 \\
(0 .\end{array}$ & $\begin{array}{l}3 * * \\
88)\end{array}$ \\
\hline Background & & & & $\begin{array}{l}1 * * \\
68)\end{array}$ & & $\begin{array}{l}954 \\
112)\end{array}$ & $\begin{array}{r}0 . \\
(0 .\end{array}$ & & & & $\begin{array}{l}0.7 \\
(0\end{array}$ & $\begin{array}{l}21 * * \\
068)\end{array}$ & $\begin{array}{l}0.5 \\
(0 .\end{array}$ & $\begin{array}{l}8 * * \\
76)\end{array}$ \\
\hline Stayer & $\begin{array}{l}0.7 \\
(0\end{array}$ & & $\begin{array}{l}0.5 \\
(0\end{array}$ & $\begin{array}{l}9 * * \\
29)\end{array}$ & $\begin{array}{l}0.6 \\
(0\end{array}$ & $\begin{array}{l}96 * * \\
50)\end{array}$ & $\begin{array}{l}0.7 \\
(0 .\end{array}$ & $\begin{array}{l}8 * * \\
62)\end{array}$ & $\begin{array}{l}0.6 \\
(0\end{array}$ & $\begin{array}{l}6^{* * *} \\
28)\end{array}$ & $\begin{array}{l}0.6 \\
(0\end{array}$ & $\begin{array}{l}52 * * \\
548)\end{array}$ & $\begin{array}{l}0.6 \\
(0 .\end{array}$ & $\begin{array}{l}0 * * \\
57)\end{array}$ \\
\hline $\begin{array}{l}\text { Years of } \\
\text { commuting }\end{array}$ & & & & $\begin{array}{l}3 * * \\
13)\end{array}$ & & $7 * *$ & $\begin{array}{l}1.0 \\
(0 .\end{array}$ & $\begin{array}{l}2 * * * \\
19)\end{array}$ & $\begin{array}{l}1.0 \\
(0 .\end{array}$ & 9** & $\begin{array}{r}1.0 \\
(0\end{array}$ & $\begin{array}{l}\text { 78*** } \\
013)\end{array}$ & $\begin{array}{l}1.0 \\
(0 .\end{array}$ & $\begin{array}{l}4 * * \\
23)\end{array}$ \\
\hline $\begin{array}{l}\text { Commuter, } \\
\text { urban }\end{array}$ & & & & & & $\begin{array}{l}75 \\
788)\end{array}$ & $\begin{array}{r}0 . \\
\text { (0. }\end{array}$ & & & & & $\begin{array}{l}917 \\
069)\end{array}$ & $\begin{array}{r}0 . \\
(\mathbf{0} .\end{array}$ & \\
\hline Occupation & & & & & & $\mathrm{O}$ & & & & & & $E S$ & & \\
\hline $\begin{array}{l}\text { Establishment } \\
\text { size }\end{array}$ & $\begin{array}{r}0.2 \\
(0 \\
\end{array}$ & & $\begin{array}{l}0.3 \\
(0 \\
\end{array}$ & $\begin{array}{l}9 * * \\
08) \\
\end{array}$ & $\begin{array}{l}0.2 \\
(0 \\
\end{array}$ & $\begin{array}{l}52 * * \\
009)\end{array}$ & $\begin{array}{l}0.2 \\
(0 .\end{array}$ & $\begin{array}{l}8 * * \\
08) \\
\end{array}$ & $\begin{array}{l}0.2 \\
(0\end{array}$ & $\begin{array}{l}9 * * \\
05) \\
\end{array}$ & $\begin{array}{r}0.3 \\
(0 \\
\end{array}$ & $\begin{array}{l}18 * * \\
014)\end{array}$ & $\begin{array}{l}0.3 \\
(0 .\end{array}$ & $\begin{array}{l}8 * * \\
19)\end{array}$ \\
\hline Economic env & onment & & & & & & & & & & & & & \\
\hline & Work & Home & Work & Home & Work & Home & Work & Home & Work & Home & Work & Home & Work & Home \\
\hline $\begin{array}{l}\text { Network } \\
\text { municipality }\end{array}$ & $\begin{array}{l}1.067 * * \\
(0.031)\end{array}$ & $\begin{array}{c}1.156 * * \\
(0.052) \\
\end{array}$ & $\begin{array}{c}0.886 * * \\
(0.032) \\
\end{array}$ & $\begin{array}{c}1.067 * * \\
(0.028)\end{array}$ & $\begin{array}{c}0.953 \\
(0.031)\end{array}$ & $\begin{array}{r}\text { 1.111** } \\
(0.044)\end{array}$ & $\begin{array}{c}1.019 \\
(0.036)\end{array}$ & $\begin{array}{c}1.072 \\
(0.051)\end{array}$ & $\begin{array}{c}0.930 * * \\
(0.022)\end{array}$ & $\begin{array}{c}1.086 * * \\
(0.030)\end{array}$ & $\begin{array}{c}0.930 \\
(0.032)\end{array}$ & $\begin{array}{c}1.114 * * \\
(0.038)\end{array}$ & $\begin{array}{c}1.002 \\
(0.042)\end{array}$ & \begin{tabular}{|c|}
1.073 \\
$(0.060)$
\end{tabular} \\
\hline & Work & Home & Work & Home & Work & Home & Work & Home & Work & Home & Work & Home & Work & Home \\
\hline $\begin{array}{l}\text { Network } \\
\text { region }\end{array}$ & $\begin{array}{c}1.048 \\
(0.031)\end{array}$ & $\begin{array}{r}1.097 * * \\
(0.049)\end{array}$ & $\begin{array}{c}0.984 \\
(0.028)\end{array}$ & $\begin{array}{c}0.994 \\
(0.030)\end{array}$ & $\begin{array}{l}0.927 * \\
(0.028)\end{array}$ & $\begin{array}{c}1.007 \\
(\mathbf{0 . 0 4 3})\end{array}$ & $\begin{array}{c}0.974 \\
(0.028)\end{array}$ & $\begin{array}{c}\mathbf{0 . 9 6 0} \\
(\mathbf{0 . 0 3 7}) \\
\end{array}$ & $\begin{array}{c}0.983 \\
(0.025)\end{array}$ & $\begin{array}{c}0.988 \\
(0.020)\end{array}$ & $\begin{array}{c}0.976 \\
(0.025)\end{array}$ & $\begin{array}{c}1.064 \\
(0.039)\end{array}$ & $\begin{array}{c}1.026 \\
(0.042)\end{array}$ & $\begin{array}{c}1.037 \\
(\mathbf{0 . 0 6 1}) \\
\end{array}$ \\
\hline$N$ & & & & & & 531 & & & 153 & 847 & & 196 & 30 & 362 \\
\hline Wald chi ${ }^{2}$ & & & & & & 39 & & & & & & 900 & & \\
\hline Pseudo $R^{2}$ & & & & & & 33 & & & & & & 34 & & \\
\hline
\end{tabular}

** significant at 1 percent, *significant at 5 percent. Cluster (municipality) standard errors within parenthesis. Control for educational, regional type and industry. 
In the last scenario we observe those individuals that commute long-distances, i.e. here defined as across functional regions. This gives us the opportunity to analyse the work and home economic environment at the municipal and regional level. Starting with the local environment (Network municipality) there is no consistent pattern across occupational groups. For individuals having a cognitive occupation both the network opportunities in the home and work municipality increase the prospects in becoming self-employed. For the other occupation groups, except individuals with a standardized occupation, it is the network built up in the home municipality that is important. The network opportunities in the work municipality is even hampering the effect of becoming self-employed in some cases. The regional level (Network region) does not overall influence the decision to become selfemployed. The only case where it is significant and positive is for individuals with a cognitive occupation where the work environment is important. For individuals with a social occupation having access to many other self-employed in the home region is negatively associated with the probability of becoming self-employed.

Again, we confirm that commuting to more urban locations (Commuter, urban) does not influence the choice of self-employment. How long time you have commuted (Years of commuting) is however positively associated with choosing to become self-employed, irrespectively of occupation and years of schooling. Building on this we would also like to analyse if there is any optimal time-length for commuting. We start by simply checking if the is a decreasing marginal effect from commuting by adding the squared years of commuting in the estimation. By adding this variable there is no consistent pattern across occupational groups and educational levels. We follow this up by also including dummies for each year that an individual can commute, i.e. one to ten, and see which of the dummies have the highest coefficient (using ten years of commuting as a base). Here we find a more consistent pattern where the probability of becoming self-employed is a function of the number of years commuting. Thus, as the network grow stronger you are more willing to become selfemployed. 


\section{Conclusions}

In this paper, we have analysed how the "business network" characteristics of work and home localities and work and home region of individuals influence their probability of becoming self-employed. By making a distinction between non-commuters, and short- and long-distance commuters we are able to highlight the influence of the "business network" characteristics. The results are not totally clear-cut but we show a number of interesting results. For noncommuters we find that living and working in a locality with rich "business networks" significantly reduces the probability of becoming self-employed except for those with a high education. On the other hand living and working in a labour market region with rich "business networks" increases significantly the probability of becoming self-employed. Why "business networks" have different effects at the locality level and the level of the labour market region is a question for future research.

For short-distance commuters, rich "business networks" in the work locality has a significant positive effect on the probability to become self-employed except for those in management and administrative occupations, where the effect is insignificant. Perhaps, those in management and administrative occupations due to their work tasks and work experience have so much insights in becoming self-employed that they are not dependent on stimuli from those that already are self-employed. Interestingly, rich "business networks" in the home locality has no significant effects. Rich "business networks" at the regional level is only significantly positive in one case and significantly negative in one case. It is a question for future research to find out why we have this difference between non-commuters and shortdistance commuters in terms of the effects of "business networks" at the regional level.

Long-distance commuters seem to differ from short-distance commuters in the sense that for them in five out of seven categories we get a significant positive effect on the probability of becoming self-employed from rich "business networks" in the home locality. The business networks in the home and work regions in almost all cases show insignificant effects. If we summarise, our results indicate that obviously rich "business networks" are important for peoples' decision to become self-employed. However, the effects are quite different for noncommuters, short-distance and long-distance commuters which implies that we have to dig deeper into this question in future research. 


\section{References}

Almeida, P., and Kogut, B. (1997). The Exploration of Technological Diversity and Geographic Localization in Innovation: Start-Up Firms in the Semiconductor Industry. Small Business Economics, 9(1), 21-31.

Almeida, P., and Kogut, B. (1999). Localization of Knowledge and the Mobility of Engineers in Regional Networks. Management Science, 45(7), 905-917.

Almeida, P., and Phene, A. (2012). Managing Knowledge Within and Outside the Multinational Corporation. In M. Andersson, B. Johansson, C. Karlsson and H. Lööf (Eds.), Innovation and Growth. From R\&D Strategies of Innovating Firms to Economy-Wide Technologi-cal Change (pp. 21-37). Oxford: Oxford University Press.

Andersson, M., and Larsson, J. P. (2013). Neighborhood Peers and Entrepreneurship - Does Having Entrepreneurs as Residential Neighbors Induce Entrepreneurship? (Vol. No 2013/30). Lund: CIRCLE, Center for Innovation, Research and Competences in the Learning Economy, Lund University.

Arrow, K. J. (1962). The Economic Implications of Learning by Doing. Review of Economic Studies, 29(3), 155-173.

Audretsch, D. B., and Keilbach, M. (2007). The Theory of Knowledge Spillover Entrepreneurship*. Journal of Management Studies, 44(7), 1242-1254.

Audretsch, D. B., and Lehmann, E. E. (2005). Does the Knowledge Spillover Theory of Entrepreneurship hold for regions? Research Policy, 34(8), 1191-1202.

Autant-Bernard, C., Billand, P., and Massard, N. (2012). Innovation and space: From externalities to networks. In C. Karlsson, B. Johansson and R. R. Stough (Eds.), The Regional Economics of Knowledge and Talent. Local Advantage in a Global Context (pp. 63-97). Cheltenham: Edward Elgar.

Backman, M., and Karlsson, C. (2013). Determinants of Entrepreneurship: Is It All about the Individual or the Region? International Review of Entrepreneurship 11(3).

Baker, T., Gedajlovic, E., and Lubatkin, M. (2005). A Framework for Comparing Entreprenurship Processes Across Nations Journal of International Business Studies, 36, 492-504.

Bates, T. (1995). Self-employment entry across industry groups. Journal of Business Venturing, 10(2), 143-156.

Bathelt, H., Malmberg, A., and Maskell, P. (2004). Clusters and knowledge: local buzz, global pipelines and the process of knowledge creation. Progress in Human Geography, 28(1), 31-56.

Blanchflower, D., and Meyer, B. (1994). A longitudinal analysis of the young self-employed in Australia and the United States. Small Business Economics, 6(1), 1-19.

Blanchflower, D. G. (2000). Self-employment in OECD countries. Labour Economics, 7(5), 471-505.

Borgatti, S. P., and Halgin, D. S. (2011). On Network Theory. Organization Science, 22(5), 1168-1181.

Breschi, S., and Lissoni, F. (2006a). Cross-Firms Inventors and Social Networks: Localised Knowledge Spillovers Revisited Annales d'Economie et de Statistique, 79-80, 189-209.

Breschi, S., and Lissoni, F. (2006b, 14-15 September ). Mobility of Inventors and the Geography of Knowledge Spillovers. New Evidence on US Data. Paper presented at the ADRES Conference, St Etienne.

Brunello, G., and De Paola, M. (2004). Market Failures and Under-Provision of Training: CES Info Paper, Business Innovation Department, 2010. Skills for Growth: The National Skills Strategy, BIS Economic Paper No. 4.

Burt, R. S. (1992). Structural Holes: The Holes Structure of Competition. Cambridge, MA: Harvard University Press.

Button, K., Nijkamp, P., and Priemus, H. (1998). Transport Networks in Europe. Cheltenham: Edward Elgar.

Cappelin, R. (2003). Networks and Technological Change in Regional Clusters. In J. Bröcker, D. Dohse and R. Soltwedel (Eds.), Innovation Clusters and Interregional Competition (pp. 52-78). Berlin: Springer. 
Carayol, N., and Roux, P. (2007). The Strategic Formation of Inter-Individual Collaboration Net-works. Evidence from Co-Invention Patterns. Annales d'Economie et de Statistique, 87-88, 275-301.

Carayol, N., and Roux, P. (2009). Knowledge flows and the geography of networks: A strategic model of small world formation. Journal of Economic Behavior \& Organization, 71(2), 414-427.

Carayol, N., Roux, P., and YıldızoĞlu, M. (2008). Inefficiencies in a model of spatial networks formation with positive externalities. Journal of Economic Behavior \& Organization, 67(2), 495-511.

Carroll, G. R., and Mosakowski, E. (1987). The Career Dynamics of Self-Employment. Administrative Science Quarterly, 32(4), 570-589.

Cohen, W. M., and Levinthal, D. A. (1990). Absorptive Capacity: A New Perspective on Learning and Innovation. [Article]. Administrative Science Quarterly, 35(1), 128-152.

Coleman, J. S. (1988). Social Capital in the Creation of Human Capital. The American Journal of Sociology, 94, S95-S120.

Cowan, R., Jonard, N., and Zimmermann, J. B. (2006). Evolving networks of inventors. Journal of Evolutionary Economics, 16(1-2), 155-174.

Dorfman, N. S. (1987). Innovation and Market Structure: Lessons from the Computer and Semiconductor Industries. Cambridge: Ballinger.

Dow, S., and Zolnik, E. J. (2012). Social Capital and Entrepreneurship: An Empirical Analysis of the Role of Social Capital in Self-Employment. In C. Karlsson, B. Johansson \& R.R. Stough (Ed.), Entrepreneurship, Social Capital and Governance. Direction for Sustainable Development and Competitiveness of Regions (pp. 160-191). Cheltenham: Edward Elgar.

Gennaioli, N., La Porta, R., Lopez-de-Silanes, F., and Shleifer, A. (2013). Human Capital and Regional Development. The Quarterly Journal of Economics, 128(1), 105-164.

Glaeser, E. L. (1999). Learning in Cities. Journal of Urban Economics, 46(2), 254-277.

Goldstein, G., and Gronberg, T. (1984). Economies of Scope and Economeis of Agglomeration. Journal of Urban Economcis, 16, 91-104.

Gompers, P., and Lerner, J. (2001). The Venture Capital Revolution. The Journal of Economic Perspectives, 15(2), 145-168.

Graham, M. (1985). Industrial Research in the Age of Big Science. In R. Rosenbloom (Ed.), Research on Technological Innovation, Management and Policy (Vol. 2, pp. 47-49). Greenwich: JAI Press.

Granovetter, M. S. (1973). The Strength of Weak Ties. American Journal of Sociology, 78, 1360-1380.

Granovetter, M. S. (1985). Economic Action and Social Structure: The Problem of Embed-dedness. American Journal of Sociology 91, 481-510.

Hammond, G. W., and Gurley-Calvez, T. (2012). Heterogeneity in the Determinants of Local SelfEmployment Growth by Gender, Age and Selected Industry. Regional Studies, 48(2), 339-349.

Hayek, F. A. (1945). The Use of Knowledge in Society. American Economic Review, 35(4), 519-530.

Hout, M., and Rosen, H. (2000). Self-Employment, Family Background, And Race. Journal of Human Resources, 35(4), 670-692.

landoli, L., Marchione, E., Ponsiglione, C., and Zollo, G. (2014). Knowledge Sharing and Network Emergence in Small firm Clusters: An Agent-Based Model of Industrial Districts. In C. Karlsson, B. Johansson and R. R. Stough (Eds.), Agglomeration, Clusters and Entrepreneurship. Studies in Regional Economic Development (pp. 66-84). Cheltenham: Edward Elgar.

Jackson, M. O., and Rogers, B. W. (2005). The Economics of Small Worlds. Journal of the European Economic Association, 3(2-3), 617-627.

Jackson, M. O., and Wolinsky, A. (1996). A Strategic Model of Social and Economic Networks. Journal of Economic Theory, 71(1), 44-74.

Jacobs, J. (1969). The Economy of Cities. New York, NY: Random House

Johansson, B., and Klaesson, J. (2011). Creative Milieus in the Stockholm region. In D. E. Andersson, A. E. Andersson and C. Mellander (Eds.), Handbook of Creative Cities. Cheltenham: Edward Elgar Publishing Ltd.

Johansson, B., Klaesson, J., and Olsson, M. (2002). Time distances and labor market integration. Papers in Regional Science, 81(3), 305-327. 
Johansson, B., Klaesson, J., and Olsson, M. (2003). Commuters' non-linear response to time distances. Journal of Geographical Systems, 5(3), 315-329.

Johnson, C., and Gilles, R. P. (2003). Spatial Social Networks. In B. Dutta and M. Jackson (Eds.), Networks and Groups (pp. 51-77): Springer Berlin Heidelberg.

Jones, C., Hesterly, W. S., and Borgatti, S. P. (1997). A General Theory of Network Governance: Exchange Conditions and Social Mechanisms. Academy of Management Review, 22(4), 911945.

Karlsson, C., and Manduchi, A. (2001). Knowledge Spillovers in a Spatial Context - A Critical Review and Assessment In F. M. M. F. J. (Ed.), Knowledge, Complexity and Innovation Systems (pp. 101-123). Berlin: Springer-Verlag.

Kirzner, I. M. (1973). Competition and Entrepreneurship. Chicago, IL: University of Chicago Press.

Langlois, R. N. (1992). Transaction-cost Economics in Real Time. Industrial and Corporate Change, 1(1), 99-127.

Lawton Smith, H., and Romeo, S. (2013). Business Networking in Oxfordshire. Scope and Regional Dynamics. In C. Karlsson, B. Johansson \& R.R. Stough (Ed.), Entrepreneurial Knowledge, Technology and the Transformation of Regions (pp. 97-117). London: Routledge.

Lincoln, J. R., and Miller, J. (1979). Work and Friendship Ties in Organizations: A Comparative Analysis of Relation Networks. Administrative Science Quarterly, 24(2), 181-199.

Love, J. H., and Roper, S. (2001). Outsourcing in the innovation process: Locational and strategic determinants. Papers in Regional Science, 80(3), 317-336.

McPherson, M., Smith-Lovin, L., and Cook, J. M. (2001). Birds of a Feather: Homophily in Social Networks Annual Review of Sociology, 27, 415-444.

Nahapiet, J., and Ghoshal, S. (1998). Social Capital, Intellectual Capital, and the Organizational Advantage. Academy of Management Review, 23(2), 242-266.

Nooteboom, B. (2004). Interfirm Collaboration. Learning and Networks. An Integrated Approach. London: Routledge.

Nyström, K. (2012). Regional Institutional Environment and New Firm Formation. In C. Karlsson, B. Johansson and R. R. Stough (Eds.), The Regional Economics of Knowledge and Talent. Local Advantage in a Global Context (pp. 213-232). Cheltenham: Edward Elgar.

Parker, S. C. (2004). The Economics of Self-Employment and Entrepreneurship. Cambridge, UK: Cambridge University Press.

Patel, P., and Pavitt, K. (1991). Large Firms in the Production of World's Technology: An Important Case of "Non-Globalization". Journal of International Business Studies, 22, 1-21.

Podolny, J. M., and Page, K. L. (1998). Network Forms of Organization. Annual Review of Sociology, 24(1), 57-76.

Porter, M. E. (2000). Location, Competition, and Economic Development: Local Clusters in a Global Economy. Economic Development Quarterly, 14(1), 15-34.

Powell, W. W. (1991). Expanding the Scope of Institutional Analysis. In W. W. Powell and P. J. Di Maggio (Eds.), The New Institutionalism in Organisational Analysis (pp. 183-203). Chicago: University of Chigago Press.

Putnam, R. D., Leonardi, R., and Nanetti, R. Y. (1993). Making Democracy Work: Civic Traditions in Modern Italy. Princeton: Princeton University Press.

Rogers, E., and Larsen, J. (1984). Silicon Valley Fever. New York, NY: Basic Books.

Rosenthal, S. S., and Strange, W. C. (2008). The attenuation of human capital spillovers. Journal of Urban Economics, 64(2), 373-389.

Saxenian, A. (1990). Regional Networks and the Resurgence of Silicon Valley. [Article]. California Management Review, 33(1), 89-112.

Scheinkman, J. A. (2008). Social Interactions (Theory), . In S. Durlauf and L. Blume (Eds.), The New Palgrave Dictionary of Economics Online. Baskingstoke, UK: Palgrave Macmillan.

Sena, V., Scott, J., and Roper, S. (2012). Gender, borrowing patterns and self-employment: some evidence for England. Small Business Economics, 38(4), 467-480. 
Shane, S. (2000). Prior Knowledge and the Discovery of Entrepreneurial Opportunities. Organization Science, 11(4), 448-469.

Singh, J. (2005). Collaborative Networks as Determinants of Knowledge Diffusion Patterns. Management Science, 51(5), 756-770.

Taylor, M. P. (1999). Survival of the Fittest? An Analysis of Self-Employment Duration in Britain. The Economic Journal, 109(454), 140-155.

Uzzi, B. (1996). The Sources and Consequences of Embeddedness for the Economic Performance of Organizations: The Network Effect. American Sociological Review, 61(4), 674-698.

Uzzi, B. (1999). Embeddedness in the Making of Financial Capital: How Social Relationships and Networks Benefit Firms Seeking Financing American Sociological Review, 64, 481-505.

Uzzi, B., and Spiro, J. (2005). Collaboration and Creativity: The Small World Problem. Journal of Sociology, 111, 447-504.

Zucker, L. G., Darby, M. R., and Armstrong, J. (1998). Geographically Localized Knowledge: Spillovers or Markets? Economic Inquiry, 36(1), 65-86. 